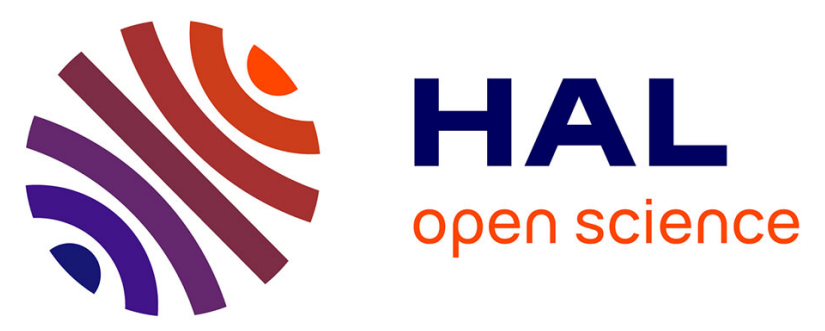

\title{
Toward a social-ecological approach to ecological restoration: a look back at three decades of maritime clifftop restoration
}

Maxime Leroy, Jérôme Sawtschuk, Frédéric Bioret, Sébastien Gallet

\section{- To cite this version:}

Maxime Leroy, Jérôme Sawtschuk, Frédéric Bioret, Sébastien Gallet. Toward a social-ecological approach to ecological restoration: a look back at three decades of maritime clifftop restoration. Restoration Ecology, 2019, 27 (1), pp.228-238. 10.1111/rec.12849 . hal-01915340

HAL Id: hal-01915340

https://hal-univ-rennes1.archives-ouvertes.fr/hal-01915340

Submitted on 7 Nov 2018

HAL is a multi-disciplinary open access archive for the deposit and dissemination of scientific research documents, whether they are published or not. The documents may come from teaching and research institutions in France or abroad, or from public or private research centers.
L'archive ouverte pluridisciplinaire HAL, est destinée au dépôt et à la diffusion de documents scientifiques de niveau recherche, publiés ou non, émanant des établissements d'enseignement et de recherche français ou étrangers, des laboratoires publics ou privés. 


\title{
Toward a social-ecological approach to ecological restoration: a look back at three decades of maritime clifftop restoration
}

\author{
Maxime Le Roy ${ }^{1}$, Jérôme Sawtschuk ${ }^{1,2}$, Frédéric Bioret ${ }^{1}$, Sébastien Gallet ${ }^{1}$ \\ ${ }^{1}$ EA 7462 Géoarchitecture - Territoires, Urbanisation, Biodiversité, Environnement, Université de Bretagne Occidentale, UFR Sciences et Technique, CS 93837, 29238 \\ Brest Cedex 2, France \\ ${ }^{2}$ Address correspondence to J. Sawtschuk, email jerome.sawtschuk@univ-brest.fr
}

The sharp increase in the touristic use of the maritime clifftops in western France after WWII resulted in a concentration of activities that generated ecosystem degradation in many sites (e.g. touristic infrastructure, human trampling). Consideration of the ecological value of these sites over the past three decades has led to a shift in maritime clifftop management and consequently to numerous planning and restoration projects. Using inventories of maritime clifftop restoration projects conducted in 2007 and 2016, we identified 76 restoration projects, which allowed us to study the active and passive restoration methods used. In addition, we collected and analyzed 465 vegetation monitoring plots with an average duration of 5.6 years to understand how they were used by both scientists and nonscientists. First, we describe the social-ecological systems of these restoration projects through an analysis of their social contexts, ecological stakes, and restoration goals based on 19 semistructured interviews with restoration stakeholders. Comparing our research with similar studies in the literature reveals that the main strength of maritime clifftop restorations is a strong network between scientist and nonscientist stakeholders combined with high-level monitoring. Finally, we underline the main challenges for the future of maritime clifftop ecological restoration: (1) the need for further study of this ecological database (e.g. to study the medium-term effect of active restoration, continue current monitoring); and (2) the need to develop sociological studies of human uses and perceptions to improve the long-term management of restored ecosystems.

Key words: goals, maritime clifftop, restoration methods, restoration monitoring, social-ecological systems, stakeholders

\section{Implications for Practice}

- Surveys (e.g. questionnaires, semistructured interviews) should be conducted to better understand users' perceptions and improve the long-term management of restoration sites.

- Stakeholders do not learn enough from past experiences. Active collaborations, for example through thematic workshops (e.g. on the subject of monitoring or assessment methods), between scientists and practitioners are therefore necessary.

- The development of an easy-to-use social and ecological indicator is needed to assess restoration projects. Such an indicator might lead to a better appropriation of ecological monitoring by site managers, allowing them to adjust restoration methods and transfer results to scientists and practitioners.

\section{Introduction}

In 2004, the Society for Ecological Restoration defined the characteristics of restored ecosystems for their potential use as objectives in restoration plans. In most cases, restoration projects aim to reach a reference state or to restore indigenous species, and objectives are defined on the basis of an ecosystem structure and composition. Goals are also commonly related to ecosystem function and social values (Hallett et al. 2013). However, it appears that this planning phase is often underestimated during restoration projects (Clewell \& Aronson 2006).

In terms of achieving restoration goals, passive and active restoration methods are the two possible options in a restoration project (McIver \& Starr 2001). The first uses the resilience capacity of an ecosystem where restoration action is reduced to the limitation or removal of a feature that is preventing natural restoration (McIver \& Starr 2001), such as the use of fencing to limit the impacts of human trampling. The second is achieved through technical measures that improve or replace natural processes (Prach \& Hobbs 2008). Active restoration can be implemented through management methods (e.g. mowing),

\footnotetext{
Author contributions: MLR, JS conceived and wrote the manuscript; FB, SG provided feedback to improve different versions of the manuscript; all authors edited
} the manuscript. 
ecological engineering methods (e.g. soil removal), or civil engineering methods (e.g. building removal).

Ecological issues are not the only factors that should be considered. Restoration sites should also be considered as social-ecological systems (Rissman \& Gillon 2017). In other words, it is important to take into account both the social and ecological issues and the interactions between them (Hobbs 2007; Gunderson et al. 2010) in order to understand all the issues related to a site (Lowe et al. 2009; Wyborn et al. 2012). Many studies incorporating the social aspect have done so from the perspective of ecosystem functions restoration (Rumps et al. 2007; Fernández-Manjarrés et al. 2018), which does not take into consideration all the social aspects necessary for restoration success. For instance, the requirement for social acceptance might be met through the use of effective communication (Metcalf et al. 2015). A good understanding of each stakeholder's goals and values is also essential (Guerrero et al. 2017) when planning restoration projects. More broadly, human goals and values might also be considered as part of an ecosystem (Wiens \& Hobbs 2015) when planning restoration projects. However, it is still rare to see all these issues taken into account in restoration contexts (Perring et al. 2015) due to a lack of consideration of social issues (Aronson et al. 2010).

This article focuses on the specific case of the maritime clifftops in Brittany, France, which have been followed by scientists for the past three decades (Bioret 1989; Bioret \& Brigand 1993; Gallet et al. 2004, 2009; Sawtschuk 2010; Sawtschuk et al. 2010; Gallet et al. 2011; Sawtschuk et al. 2012, 2015). These clifftops present particular conditions for flora and fauna due to their strong environmental stresses, mainly involving wind and salt deposition (Malloch 1972; Sawtschuk 2010). The unusual conditions have led to the establishment of maritime grasslands (e.g. characterized by Festuca rubra ssp. pruinosa) and coastal heathlands (e.g. characterized by Erica cinerea, Ulex gallii var. humilis), both of which are protected by European legislation. These cliffs are also important for maritime bird conservation because of the nesting sites they offer (Le Corre 2009).

At some sites, these ecological stakes can be threatened by the colonization of invasive vegetal species (e.g. Carpobrotus edulis) (Sawtschuk et al. 2012), which can compete with the native vegetation (D'Antonio \& Meyerson 2002). However, the main threat to this system comes from human practices, particularly those related to tourism. Tourism activities can develop out of different motivations (Arnegger et al. 2010), such as hedonism or sport and adventure practices. All of these practices have led to the creation of a dense network of paths in the clifftop vegetation (Fig. 1). Hedonistic tourists were present, mainly during summer, in all the sites studied (Gallet et al. 2004). Some maritime cliffs, like the Pointe du Raz and the Cap Fréhel (Le Fur 2013), can attract more than 1 million tourists annually. In addition to these regular visitors, nautical events may increase visitor numbers even further (e.g. 50,000 visitors, in 1 day, to the Cap Fréhel every 4 years for the departure of a popular boat race). This high trampling pressure affects both vegetation composition and soil structure (Liddle 1975) over areas up to 100 ha. Furthermore, to support demand from these

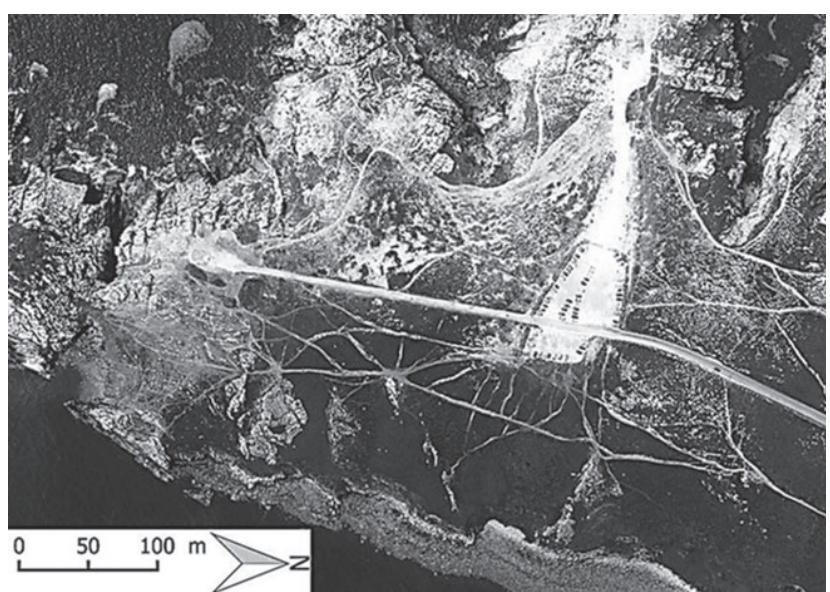

Figure 1. Aerial photograph of Pointe de Pen-Hir showing a dense network of paths created by hedonistic tourists, fishers, rock climbers, and hikers. Source, BD ORTHO ${ }^{\circledR}$ IGN 2012.

high visitor numbers and generate income, the construction of hotels, restaurants, and shops (Le Fur 2013) has caused the complete destruction of vegetation and soil (Gallet \& Roze 2001).

The first restoration projects were set up in the 1980s in response to such cases of vegetation degradation. Since then, however, there has been no review of maritime clifftop restoration practices such as those that exist for other types of ecosystems, such as peatlands (Andersen et al. 2016; Chimner et al. 2016), forests (Halme et al. 2013), and rivers (Kondolf et al. 2007). These reviews are essential to focus future research, allowing the most effective restoration strategies to be applied in future projects.

In this study, we considered maritime clifftops to be social-ecological systems in which the natural ecosystem and human activities coexist. We identified the main developments in maritime clifftop restoration over the past 30 years. The social (e.g. stakeholder interactions, knowledge sharing) and ecological (e.g. the restoration and monitoring methods used) aspects were compared with current knowledge and theory in the field of restoration ecology. Our aim was to describe the current state of maritime clifftop restoration in order to highlight its main strengths and weaknesses. We thus focused on three research questions pertaining to these restorations: (1) are both social and ecological issues considered in restoration projects? (2) Are we able to assess the effectiveness of restoration methods? (3) Has the restoration ecology knowledge produced in our early projects been used for more recent ecological restoration projects?

\section{Methods}

\section{Study Sites}

The study was based on 36 maritime clifftop sites along Brittany's coastline (western France) that either had been or were currently subject to a restoration project (Fig. 2). Heathlands 


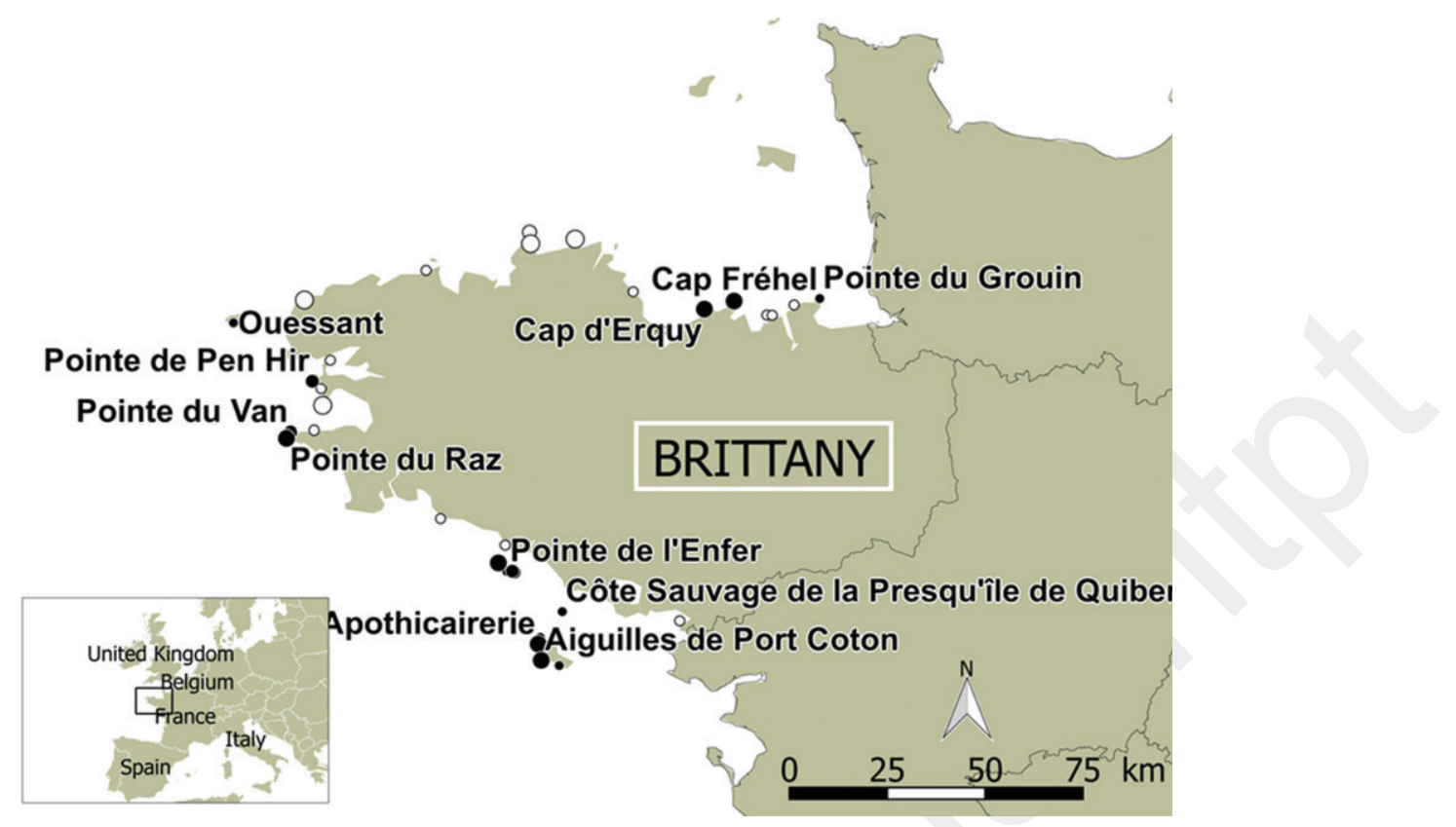

Figure 2. Location and number of restoration projects on Breton maritime clifftops. Projects with at least one monitoring plot are shaded black. Small dots: one restoration project; medium dots: two restoration projects; and large dots: three or more restoration projects.

(dominated by dwarf shrubs) and maritime grasslands (dominated by Festuca rubra ssp. pruinosa) were the typical vegetation on the sites we studied. We considered a "site" to be one geographical unit that had been restored through at least one restoration project and a "restoration project" to be composed of one or several restoration methods performed on the same site over a particular period (i.e. $<1$ year). A single restoration program (e.g. research program, funding program) could present several ecological restoration projects that had been adapted to different degradation levels or different ecosystems. Prior to restoration, these sites had all been impacted by human trampling and/or infrastructure creation.

\section{Data Collection}

Data collection was based on an inventory compiled in 2007 (Lebras 2007) and 2016 of maritime clifftop restoration projects. First, we identified the restoration sites through a survey of a large variety of stakeholders and a review of the gray literature. We then met with the different project managers to gain a better understanding of their site characteristics (e.g. ecology, landowner, site manager, protection statutes) and the restoration and assessment methods used. From this inventory, we identified and contacted the managers and scientists involved in ecological monitoring (i.e. covering at least one monitoring plot that was inventoried with the same protocol for at least 2 years). We asked them to locate monitoring plots, and we collected raw data from these plots. All datasets were compiled in a geographic information system using QGIS 2.8.8 Wien. Three layers were created: the "site" layer, which described all the restored sites in terms of their different attributes (e.g. landowner, manager, and vegetation type); the "project" layer, which described all the restoration projects conducted (e.g. funding, implementation date, and restoration methods); and the "monitoring" layer, which described all the inventoried monitoring plots (e.g. location, monitoring method, and author).

Recorded, semistructured interviews, which are part of a larger ongoing study, were conducted with 19 restoration stakeholders who were identified with the aim of covering as many profiles (five landowners, three scientists, four managers, five Natura 2000 coordinators, one naturalist, and one nature conservation officer) and as many restoration contexts as possible (with/without scientific involvement, initiated and managed by different entities, different localities, with/without known monitoring). We asked open-ended questions (see Appendix S1, Supporting Information) to allow discussion of any relevant topic. We focused on the interviewee's (1) restoration goal; (2) technical choices (restoration and monitoring methods); and (3) involvement in the project.

\section{Data Analysis}

For this database, we summarized the human uses of the clifftops, the number of restoration projects, the restoration and monitoring methods used in every 5-year period between 1980 and 2015, the number of new monitoring plots per year, and the number of different types of landowners (e.g. private, conservation agency) and site managers (local authority, nonprofit organization).

Data on restoration goals and assessment methods were extracted from the interviews. The goals were classified into five categories: "habitat restoration," "habitat conservation," "social goal," "landscape goal," or "species-scale goal." For each goal, 
we indicated whether a clear objective (e.g. restoring a specific species composition, maintaining low vegetation) or only guidelines (e.g. restoring heathland, improving landscape quality) had been set out. The different ways in which the interviewees spoke about restoration assessment were also classified into three categories: "visual assessment" (i.e. expert opinion), assessment based on photographs, and scientific assessment (i.e. based on monitoring).

\section{Results}

\section{Three Decades of Active and Passive Maritime Clifftop Restoration}

The first restoration projects were implemented at the beginning of the 1980s on sites such as La Pointe du Grouin and Cap d'Erquy in northern Brittany. Since then, at least 36 sites have been restored through one or several restoration projects (Fig. 2). Funding has come from a wide range of public bodies (e.g. European Union, local government organizations).

The types of stakeholders on the sites varied, and often multiple stakeholders were involved with one site. Of the 36 sites identified, 14 were owned or part-owned by their respective town councils and France's coastal conservation agency (Conservatoire du Littoral). The remaining ownership was made up of county (départemental) councils, private buyers, and the French navy, owning or part-owning 13, 8, and 4 sites, respectively. The managers responsible for the restoration projects were either local government organizations (31 sites) or nonprofit organizations (5 sites). External stakeholders, such as researchers and consultancies, were also occasionally involved in restoration projects.

Habitat restoration and landscape improvement were the goals most frequently cited by our interviewees. Half of the stakeholders wished to restore habitat but did not specify which types of habitat. For example, very few interviewees mentioned the specific type of heathland they wished to restore or a precise reference habitat in the local area. These goals were usually linked to the desire to restore a landscape's aesthetic value through the revegetation of degraded areas. While a quarter of the interviewees gave precise objectives for improving landscape quality (e.g. keeping heathland low, reducing path widths), another quarter just wanted to improve the landscape's aesthetic value, mainly for hedonistic tourism. This goal of improving the tourist's experience, although not always mentioned during our interviews with the stakeholders, was very common. Indeed, 29 of the 36 restored sites were managed by the installation of fencing ( 29 sites) and the creation of car parks (7 sites) for this very purpose. Only a few interviewees mentioned that they aimed to remove invasive species or "weeds."

While restoration projects also had to be managed for local activities like rock climbing and fishing (activities that spread out across the whole maritime cliff area), such activities were mentioned by less than a quarter of the stakeholders. Hiking was an omnipresent activity on the sites we studied and was integrated into restoration plans in the same way that hedonistic tourism was. Rock climbing was practiced in at least a quarter of the restoration sites. The sites generally contained fewer than 50 climbing routes, although the most famous climbing site, La Pointe de Pen-Hir, had over 130. Amateur fishing was practiced on more than half of the restoration sites. Because of the lack of any controlling structure, we were not able to estimate the exact number of fishers on these sites but they did not exceed a few dozen per day per site.

Pedestrian and vehicular reorganizations were not readily accepted by the public. For example, some climbers and fishers were still trespassing on the newly restricted areas but this was tolerated by the managers, who were not acting to enforce the ban. More forceful protests at the new layouts were evidenced in the sabotaged barriers and fences on at least seven different sites, especially where vehicular access was forbidden.

\section{Evolution of Restoration Methods}

A total of 76 restoration projects were listed for the 36 sites identified. From the beginning of the 1990s until 2005, the number of new projects increased from 4 to 24 (Table 1). From 2005 onward, there was a rapid decline from 24 new projects between 2001 and 2005 to only 6 between 2011 and 2015 . The distribution of restoration projects among the sites was not homogenous. In most cases, only one project had been implemented at a site, while some sites had benefited from three or more restoration projects (Fig. 2).

The most common restoration method was fencing, which was used in nearly two-thirds of the restoration projects (Table 1). Fences were installed to channel visitors onto a few well-designed paths and steer them away from the main part of the restoration site (Fig. 3A). The most frequent active ecological engineering method used (found in more than a quarter of the restoration projects) was biodegradable geotextile, which was laid on bare ground in order to protect seedlings (Fig. 3C). Fascines, generally made of heather, were used in a quarter of the projects to limit soil erosion on slopes. In about half the cases, these active methods were used in combination with fencing. The civil engineering methods used included nine infrastructure deconstructions (e.g. buildings, landfill sites) (Fig. 4D) and, mainly prior to 1995, seven car park constructions to limit disorganized vehicular access. Management methods, such as the removal of invasive plants (e.g. Carpobrotus spp.) and mowing, were used in 11 of 76 restoration projects (Table 1 ).

There seems to have been no clear change in the restoration methods used since the implementation of the first restoration projects in 1980. The proportion of passive and active methods has remained constant (Table 1). Around one-third of the restoration methods in every 5-year period were passive, and half the projects were composed of ecological engineering methods. Moreover, there was no change in the proportion of ecological engineering methods used since the 1980 s (Table 1).

\section{Evolution of Assessment and Monitoring Methods}

In all, there were 465 monitoring plots in the maritime cliff restoration projects identified in Brittany. The longest 
Table 1. Evolution of the number of restoration projects and number of methods used on maritime clifftop restoration projects since 1980. Bold text indicate totals.

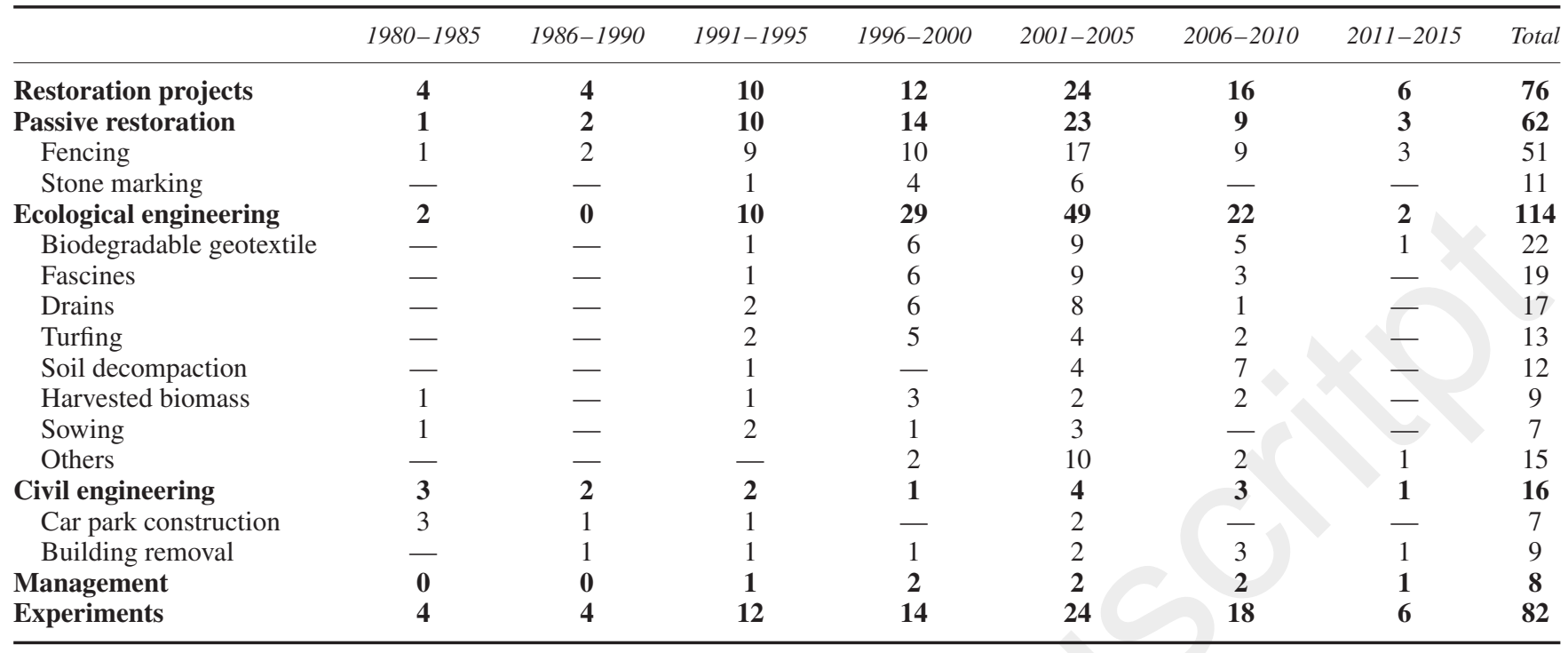
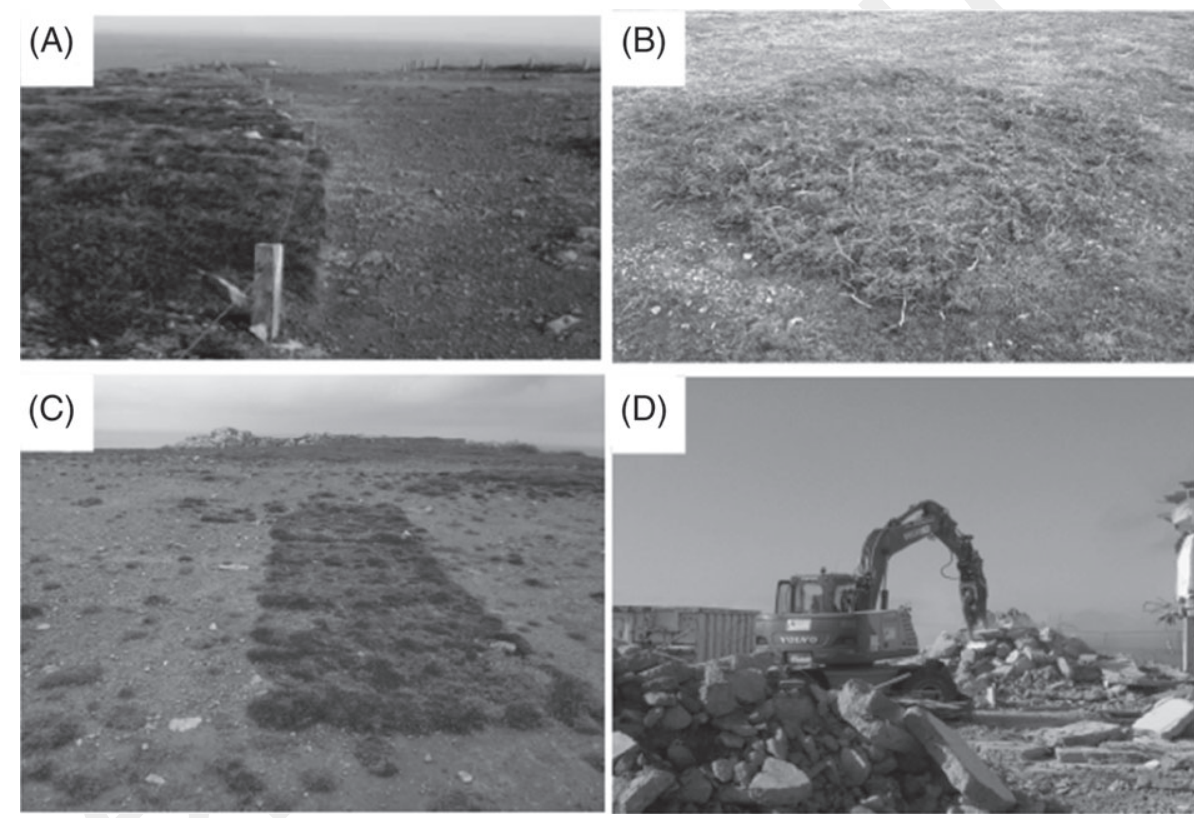

Figure 3. Different restoration methods. Passive method: (A) fence; ecological engineering method: (B) harvested biomass transfer; (C) biodegradable geotextile; civil engineering method: (D) building destruction. (Photos A, B, and C by J. Sawtschuk; Photo D by J. Froger)

monitoring data available spanned 26 years, and the average duration was 5.6 years. Monitoring data were collected heterogeneously between the different restoration sites. Only 18 of 36 restoration sites were monitored (Fig. 2), and the establishment of new monitoring plots was not regular over time (Fig. 4). With the exception of the Pointe du Raz Grand site program in 1992 and 1993, few monitoring plots were set up between 1981 and 2001. The majority of new monitoring plots were set up between 2002 and 2008, corresponding to two research programs aimed at comparing active and passive methods. One of these showed mitigated results concerning the effectiveness of an active method being tested at four different sites (Kerambrun \& Ragot, unpublished data). Conversely, Sawtschuk et al. (2012) showed that active methods, such as harvested biomass transfer and the use of biodegradable geotextile, had accelerated the short-term restoration process on two different sites. In 2005, monitoring plots were established to assess heathland management. The final two surges in the number of new monitoring plots coincided with a landfill site restoration project in 2011 and a building deconstruction in 2014. So far, no restoration assessments of such highly disturbed sites have been carried out. 


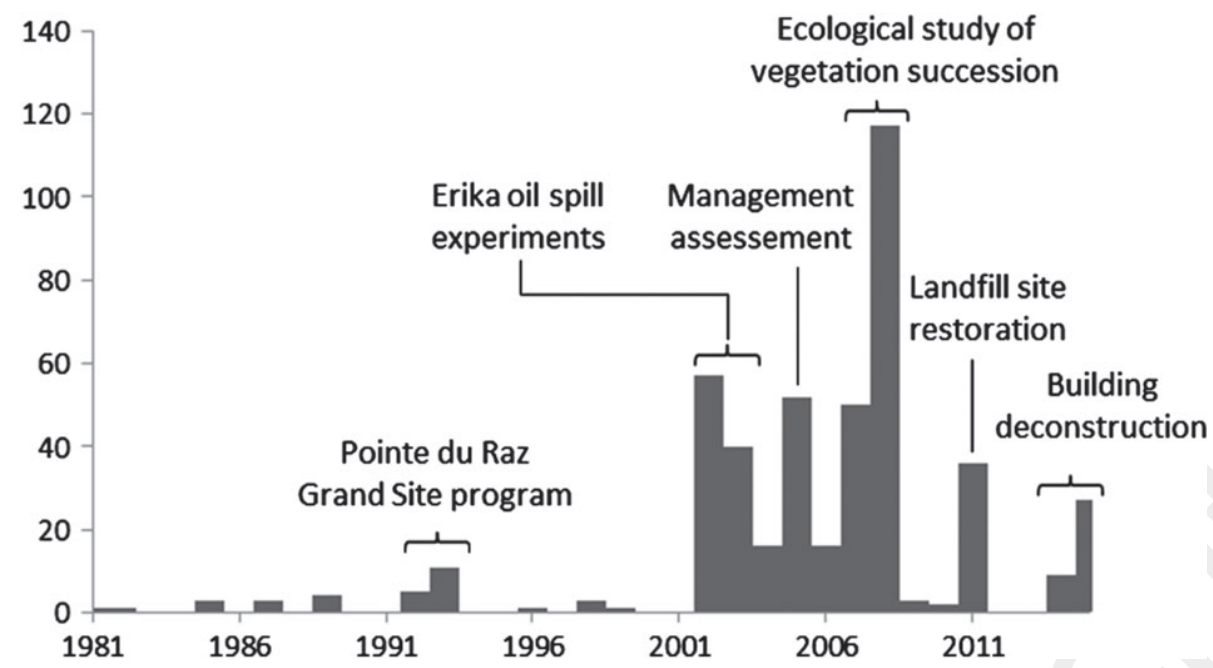

Figure 4. The evolution in the number of new maritime clifftop ecological restoration monitoring plots. The main programs are written above their corresponding periods.

Table 2. Evolution of monitoring methods used in the maritime clifftop restoration context.

\begin{tabular}{|c|c|c|c|c|c|c|c|c|}
\hline Period & $1980-1985$ & $1986-1990$ & $1991-1995$ & $1996-2000$ & $2001-2005$ & $2006-2010$ & $2011-2015$ & Total \\
\hline Quadrat & 0 & 0 & 0 & 0 & 0 & 464 & 433 & 897 \\
\hline Landscape mapping & 0 & 4 & 0 & 4 & 0 & 4 & 4 & 16 \\
\hline Habitat mapping & 1 & 0 & 0 & 3 & 5 & 3 & 6 & 18 \\
\hline Other & 4 & 8 & 1 & 2 & 9 & 0 & 70 & 94 \\
\hline
\end{tabular}

All these major restoration programs (Fig. 4) were conducted with the involvement of academic scientists. Only one of the monitoring programs was launched exclusively with the aim of experimental restoration. A second monitoring program included both experimental and applied restoration. Both of these were designed and conducted by academic and nonacademic scientists. The other four monitoring programs were implemented during applied (i.e. nonexperimental) restoration projects. All the programs were designed and conducted through manager-scientist collaborations, and all followed clear protocols, with controls and replicates allowing comparisons to be made between them. Once the experiments and monitoring programs had started, most of the responsibility for data collection fell to the researchers and very rarely to the managers.

The results of these experiments have been published in specialized scientific journals (Rozé 1995; Bioret \& Géhu 2008; Gallet et al. 2010; Sawtschuk et al. 2010, 2012) as well as in managers' handbooks for the nonscientist stakeholders (Enoul 1999; Bioret \& Gallet 2015). Numerous articles have also been published in nonindexed journals (Bioret \& Rivière 2004; Gallet et al. 2009, 2011; Sawtschuk et al. 2015). The results of the experiments and restoration projects conducted over large areas exclusively by nonscientist stakeholders have, in contrast, been transferred by site managers mostly orally and through photographs. There was only very scant written evidence and information about the restoration methods used or the effectiveness of those restoration actions.

The three monitoring methods used in the majority of cases, both by the scientists and the managers, were the quadrat (i.e. where the percentage cover of each species present in a fixed area from 0.5 to $4 \mathrm{~m}^{2}$ is recorded), point contact (i.e. where the species present every $10 \mathrm{~cm}$ along a $10 \mathrm{~m}$ transect are recorded if in contact with a vertical pin), and phytosociological methods (i.e. where Braun-Blanquet's abundance/dominance scores of each species present in a fixed area from 1 to $25 \mathrm{~m}^{2}$ are recorded) (Table 2). The point contact method has been used since 1991 in Pointe du Raz. Its use peaked between 2001 and 2005 in the restoration experiments conducted after the Erika oil spill. While the point contact method subsequently fell away, the use of the phytosociological method has remained common. Quadrats have been used over the past decade with the development of research projects on ecological restoration (Sawtschuk 2010; Bioret \& Gallet 2015) and have now also been applied to more recent restoration projects. The only study to have compared two monitoring methods used in maritime clifftop vegetation restoration was that of Gallet et al. (2010) who demonstrated that no reading variation existed between the point contact monitoring and the monitoring performed using phytosociological method.

Ecological monitoring data were used to assess restoration success by a third of the nonscientist stakeholders interviewed. 
Most of them considered that visual assessment was an adequate measure for assessing the effectiveness of a restoration project with the use of a temporal series of photographs. Two of the site managers conducted sociological surveys but the results are unpublished. One of these consisted of interviews with the public and workshops with local inhabitants with the aim of understanding restoration project perceptions and assessing the effectiveness of knowledge sharing to local inhabitants (T. Delatouche 2017, N2000 coordinator for Guidel-Ploemeur littoral and Groix island, personal communication). The second focused on path visits in order to understand how people used the different pathways before they reconfigured the site $(\mathrm{G}$. Duthion 2017, Manager in the Natural Areas Department of the county council of Ille et Vilaine, personal communication).

\section{Discussion}

\section{Balance Between Social and Ecological Outcomes}

As with many other natural environments, ecological issues concerning maritime clifftops have only been taken into consideration since the 1990s (Le Fur 2013). For example, in Iceland, nature conservation on birch woodland, heathlands, and grasslands has only really been considered since the 1990s (Aradóttir et al. 2013), and, in Europe, the restoration of peatlands also began around this time (Andersen et al. 2016). In the maritime clifftop context, restoration projects have mostly aimed to restore vegetation and landscape quality while facilitating hedonistic tourism by channeling foot and vehicle traffic. However, our interview data showed that these goals were usually set out as restoration guidelines rather than the precise and quantifiable objectives needed to assess restoration success (McDonald et al. 2016).

The answer to our question "Are both social and ecological issues considered in restoration projects?" is yes. A balance does exist but it does not include all social practices. Apart from tourism, all other human uses (e.g. fishing, car access) are excluded from most targeted social-ecological systems. The reason for this is their incompatibility with vegetation restoration because maintaining these social activities means keeping the paths open, while vegetation restoration means closing them. This common policy, which seems to be accepted by most restoration stakeholders, has led to a similar restoration pattern all over Brittany's maritime clifftops. Every practice that leads to ecological degradation is treated in the same way (i.e. hiking and sightseeing are controlled through fencing, and other activities are usually banned) in order to achieve the same level of social, ecological, or landscape impact (Table 3). This pattern may lead to a homogenization of restored sites, which are all presenting delimited paths and are all free from other activities such as tourism (Le Fur 2013).

From the stakeholder point of view (but with no supporting statistical data), this policy seemed to be accepted by most tourists. However, no information was given on other users' perceptions. In order to verify and supplement the stakeholder point of view, quantitative and qualitative studies of the human uses and perceptions (Guerrero et al. 2017) should therefore be carried out on these social-ecological systems. These studies should be accompanied by good public communication in order to gain public acceptance (Barthélémy \& Armani 2015; Metcalf et al. 2015), particularly from the fishers and climbers, who are the users most impacted by these projects.

However, as has been pointed out in other studies, some practices are not compatible with vegetation restoration goals (Miller \& Hobbs 2007). This has been shown, for example, for grassland restoration and boreal forests (Bullock et al. 2011). However, this does not mean these conflicting practices (e.g. fishing, climbing) have to be fully excluded from maritime clifftops. Restoration should be thought out at landscape scale (Weinstein 2007), with some sites dedicated to vegetation restoration and tourism acceptance and other sites left unrestored for people who prefer no restrictions because of their practices or their personal choices (Nordstrom \& Mitteager 2001).

\section{Restoration Methods Assessment}

Long-term surveys conducted on passive restoration projects have shown that typical clifftop vegetation is able to spontaneously recolonize bare soil following vegetation degradation as long as the soil has not been too damaged (Sawtschuk et al. 2010). However, the effectiveness of this method after heavy degradation, such as building deconstruction or high human trampling pressure, has not been assessed in the literature. It is possible that this degradation will have crossed biotic and abiotic thresholds (Hobbs \& Harris 2001), making passive restoration ineffective. This conclusion has been reached for some types of heavily damaged ecosystems, such as the riparian systems and the sage-steppe communities (McIver \& Starr 2001). However, passive restoration has been found to be effective at restoring some heavily damaged ecosystems, such as forests (Prach et al. 2014).

Recently, active methods have been tested in maritime clifftop areas to accelerate revegetation. Methods like harvested biomass transfer, geotextile use, and litter transfer have already proven their effectiveness in accelerating the short-term restoration process (Sawtschuk et al. 2012), although Kerambrun and Ragot (unpublished data) showed contrasting results on the effectiveness of active methods in their experiment. These studies are, however, based on short-term assessments $(<5$ years), which can lead to invalid interpretations (Saccone \& Virtanen 2016). Moreover, as in many other restoration projects (Hallett et al. 2013; Wortley et al. 2013), most of the analyses did not monitor progress against a reference ecosystem as recommended (Aronson et al. 1995; SER 2004) but instead used only controls (i.e. degraded plots without active restoration).

Such mixed conclusions prove the need for a new analytical framework incorporating longer-term monitoring (Bell et al. 2014) and defining reference ecosystems from surrounding nondegraded vegetation (SER 2004) using key attributes (McDonald et al. 2016). Moreover, the conclusions drawn from the experimental plots in the current studies should be compared with those from larger restoration projects in order to confirm that the ecological processes observed in small experimental 
Table 3. Summary of the impact of human practices on the ecological system before restoration and the impact of restoration measures on the ecological system, landscape, and social system. Estimations of restoration impact: ++, very positive; +, positive; 0 , no impact; - , negative; -- , very negative; +/-, depends on the restoration context; and ?, not determined.

\begin{tabular}{|c|c|c|c|c|c|c|}
\hline \multicolumn{3}{|c|}{ Ecological Impact of Human Practices } & \multicolumn{4}{|c|}{ Potential Impacts of Restoration measures } \\
\hline User type & Social system practices & Ecological outcomes & Restoration measures & $\begin{array}{l}\text { Ecological } \\
\text { impacts }\end{array}$ & $\begin{array}{c}\text { Landscape } \\
\text { impacts }\end{array}$ & $\begin{array}{c}\text { Social } \\
\text { impacts }\end{array}$ \\
\hline \multirow[t]{3}{*}{ Regular users } & Fishing & Path creation & Path closures & $?$ & + & - \\
\hline & $\begin{array}{l}\text { Access to cliff edge by } \\
\text { car }\end{array}$ & $\begin{array}{l}\text { Highly damaged paths } \\
\text { and areas }\end{array}$ & Car access ban & ++ & ++ & -- \\
\hline & Infrastructures & Soil destruction & Building destruction & $?$ & ++ & - \\
\hline \multirow[t]{2}{*}{ Hedonist users } & Sightseeing & $\begin{array}{l}\text { Multiple path } \\
\text { creation }\end{array}$ & Path limitations & $+/-$ & $+1-$ & + \\
\hline & & $\begin{array}{l}\text { Large areas } \\
\text { damaged }\end{array}$ & Car park creation & & & \\
\hline \multirow[t]{2}{*}{ Sport users } & Hiking & Highly damaged paths & Path limitations & + & + & 0 \\
\hline & Rock climbing & $\begin{array}{l}\text { Path creation } \\
\text { Bird disturbance }\end{array}$ & $\begin{array}{l}\text { Some climbing route } \\
\text { closures }\end{array}$ & + & 0 & $?$ \\
\hline
\end{tabular}

areas can be transposed to larger areas, which are generally only monitored through photographs. However, these photographic data could give valuable information about vegetation cover evolution (Baxendale et al. 2016) and about some species' composition changes (Michel et al. 2010).

Hence, the choice between active or passive methods, particularly for highly impacted sites (which seem quite common in ecological restoration), is still not clear (Zahawi et al. 2014, 2015; Prach \& del Moral 2015). However, the intensely monitored diversity of restoration methods and sites in maritime clifftop restoration should help to fill this gap because it will allow restoration to be adapted to different types of degradation and to different targeted reference ecosystem attributes (e.g. species composition, functionality) (McDonald et al. 2016), as is the case with other ecosystem types (Andersen et al. 2016; Chimner et al. 2016). Given this large, diversified database, new monitoring might not be essential, but new analysis using more recent data should be carried out. More importantly, the current monitoring must be continued to allow long-term assessments, in particular to determine the existence of passive restoration thresholds (Hobbs \& Harris 2001), which prevent passive restoration success in areas that are too degraded.

\section{Link Between Ecological Restoration and Restoration Ecology}

The importance of linking ecological restoration and restoration ecology through active collaborations between researchers and managers has already been shown (Roux et al. 2006; Burbidge et al. 2011; Gallet et al. 2017). Such collaborations are win-win situations because, on the one hand, the restoration projects provide sites and specific contexts for the scientists to study ecological processes and, on the other, restoration ecology enhances the different restoration practices used by the managers (Palmer et al. 2006).

In maritime clifftop restoration, knowledge is often coproduced by scientists and practitioners, and this appears to be the best way of creating knowledge (Roux et al. 2006; Gonzalo-Turpin et al. 2008). Nevertheless, this seems to have had little impact on the restoration methods used given that there has been no change in the restoration methods used for the past two decades nor any adaptive management when restoration is not working. Different hypotheses can be put forward to explain this situation. One is that the paucity of long-term restoration analyses has led to a lack of knowledge about restoration method effectiveness. Another is the lack of interest among managers in monitoring data collection and analysis. Hence, even if numerous nonscientific articles and handbooks were published, it is possible that a deficiency in knowledge sharing would still exist, as has been noted by some authors (Dettman \& Mabry 2008). It may therefore not be enough just to rely on these publications; it may also be necessary to hold workshops or provide training for decision-makers (Burbidge et al. 2011).

We did, however, notice a shift in monitoring methods from the point contact method to the quadrat method. There is no explanation for this shift in the literature. No scientific studies have proven that quadrat use is more valuable than point contact use. For this reason, this change seems more likely to be based on personal preference or custom than on any scientific motive. The time required for the methods did not seem to impact this choice either. Indeed, while managers should be more disposed to using less time-consuming methods than scientists who usually seek more precise data, all monitoring methods were equally used by both managers and scientists. However, the fact that very few studies compared monitoring protocols is a generalized issue in ecological science (Godínez-Alvarez et al. 2009). Monitoring method choices should be based on monitoring objectives and adapted according to different criteria, such as vegetation type (Leis 2015), time allowed (Baxendale et al. 2016), and the skills needed for data collection and analysis (Gallet et al. 2011).

Hence, the analyses of restoration methods and monitoring methods seem to show that neither scientists nor practitioners learn enough from past experiences. As already mentioned, new data analyses might therefore be necessary. However, stronger collaborations also seem essential to allow a better two-way 
knowledge transfer between practitioners and scientists. This could be particularly true for large-scale restoration projects, which there are currently very little data on.

\section{New Challenges for Maritime Clifftop Restoration}

Although socioeconomic knowledge has been cited as being key to the success of a restoration project (Carr \& Hazell 2006; Collier 2011; Hallett et al. 2013), we identified a lack of socioeconomic monitoring and assessment in maritime clifftop restoration. For instance, the paths created in the vegetation by the climbers, fishers, and hikers could not be easily distinguished from those created by the hedonistic tourists, even with photointerpretation. This makes it difficult to fully consider the different sources of damage in restoration plans without specific studies. A better understanding of the social system is also needed to be able to foster social acceptance of the project (Petursdottir et al. 2013) and avoid conflict, which can potentially lead to the destruction of restoration layouts. This lack of social consideration is generalized throughout ecological restoration projects (Aronson et al. 2010). Links between the social and ecological systems should therefore be strengthened, in particular by studying and considering every stakeholder point of view through surveys and workshops (Guerrero et al. 2017).

There should also be research conducted on ecosystem services, which are often used in the literature as restoration goals (Ehrenfeld 2000; Hallett et al. 2013). In the present context, two particular ecosystem services were considered, namely cultural services (e.g. improving landscape quality) and the limitation of soil erosion through fencing. However, we found no study or report dealing with ecosystem services showing an urgent need for such research.

Most of the monitoring plots in this study concerned vegetation. As a result, we are not yet able to assess the impact of high human trampling pressure on other ecosystem elements, such as soil properties. Furthermore, no data are available on invertebrate communities restoration despite the fact it has been identified as a potentially good restoration indicator (Gerlach et al. 2013). Although the bird disturbance has been identified (Kerbiriou 2006), it is not possible to quantify its impact. Hence, our focus here on the vegetation community should be widened through studies of these other groups. Finally, vegetation could be studied at the species level to look for easy-to-use indicators of the good health of restored ecosystems (Gerlach et al. 2013; González et al. 2013) in order to make assessment easier.

\section{Acknowledgments}

The authors would like to express their gratitude for all the discussions they had with the different stakeholders, too many to be named individually here, who provided essential information and opinions on maritime clifftop restoration for this article. We would also like to thank the Fondation de France for its financial support of this program and the Ministère de l'Écologie du développement durable et de l'Énergie, which funded a preliminary assessment of maritime clifftop restoration. We also gratefully acknowledge H. Martin-Brelot's contribution to the design of the semistructured interview schedule.

\section{LITERATURE CITED}

Andersen R, Farrell C, Graf M, Muller F, Calvar E, Frankard P, Caporn S, Anderson P (2016) An overview of the progress and challenges of peatland restoration in Western Europe. Restoration Ecology 25:271-282

Aradóttir ÁL, Petursdottir T, Halldorsson G, Svavarsdottir K, Arnalds O (2013) Drivers of ecological restoration: lessons from a century of restoration in Iceland. Ecology and Society 18(4):33

Arnegger J, Woltering M, Job H (2010) Toward a product-based typology for nature-based tourism: a conceptual framework. Journal of Sustainable Tourism 18:915-928

Aronson J, Dhillion S, Le Floch E (1995) On the need to select an ecosystem of reference, however imperfect: a reply to Pickett and Parker. Restoration Ecology $3: 1-3$

Aronson J, Blignaut JN, Milton SJ, Le Maitre D, Esler KJ, Limouzin A et al. (2010) Are socioeconomic benefits of restoration adequately quantified? A meta-analysis of recent papers (2000-2008) in restoration ecology and 12 other scientific journals. Restoration Ecology 18: $143-154$

Barthélémy C, Armani G (2015) A comparison of social processes at three sites of the French Rhône River subjected to ecological restoration. Freshwater Biology 60:1208-1220

Baxendale CL, Ostle NJ, Wood CM, Oakley S, Ward SE (2016) Can digital image classification be used as a standardised method for surveying peatland vegetation cover? Ecological Indicators 68:150-156

Bell SS, Middlebrooks ML, Hall MO (2014) The value of long-term assessment of restoration: support from a seagrass investigation. Restoration Ecology 22:304-310

Bioret F (1989) Contribution à l'étude de la flore et de la végétation de quelques îles et archipels ouest et sud armoricains. PhD thesis. Université de Nantes, Nantes, France

Bioret F, Brigand L (1993) Fréquentation humaine et protection des espaces naturels littoraux: un exemple de diagnostic en vue d'une stratégie d'aménagement intégrée. Bulletin d'écologie 24:96-99

Bioret F, Gallet S (2015) Restauration des végétations des hauts de falaises du littoral Manche-Atlantique. In: Guide méthodologique à l'usage des gestionnaires d'espaces naturels. Université de Bretagne Occidentale, Brest, France

Bioret F, Géhu J-M (2008) Révision phytosociologique des végétations halophiles des falaises littorales atlantiques françaises. Fitosociologia 45:75-116

Bioret F, Rivière G (2004) Pages 55-63. La flore et la végétation de l'île de Groix. Penn ar Bed 190-191. Bretagne Vivante, Brest, France

Bullock JM, Aronson J, Newton AC, Pywell RF, Rey-Benayas JM (2011) Restoration of ecosystem services and biodiversity: conflicts and opportunities. Trends in Ecology \& Evolution 26:541-549

Burbidge AH, Maron M, Clarke MF, Baker J, Oliver DL, Ford G (2011) Linking science and practice in ecological research and management: how can we do it better? Ecological Management \& Restoration 12:54-60

Carr A, Hazell D (2006) Talking frogs: the role of communication in ecological research on private land. Biodiversity and Conservation 15: 3177-3191

Chimner RA, Cooper DJ, Wurster FC, Rochefort L (2016) An overview of peatland restoration in North America: where are we after 25 years? Restoration Ecology 25:283-292

Clewell AF, Aronson J (2006) Motivations for the restoration of ecosystems. Conservation Biology 20:420-428

Collier MJ (2011) Incorporating socio-economic factors into restoration: implications from industrially harvested peatlands. Restoration Ecology 19:559-563 
D'Antonio C, Meyerson LA (2002) Exotic plant species as problems and solutions in ecological restoration: a synthesis. Restoration Ecology 10:703-713

Dettman CL, Mabry CM (2008) Lessons learned about research and management: a case study from a Midwest Lowland Savanna, U.S.A. Restoration Ecology 16:532-541

Ehrenfeld JG (2000) Defining the limits of restoration: the need for realistic goals. Restoration Ecology 8:2-9

Enoul P (1999) Restaurer nos espaces naturels : bilan d'un savoir-faire en région Bretagne. Institut régional du patrimoine de Bretagne, Rennes, France

Fernández-Manjarrés JF, Roturier S, Bilhaut A-G (2018) The emergence of the social-ecological restoration concept. Restoration Ecology 26: 404-410

Gallet S, Roze F (2001) Resistance of Atlantic Heathlands to trampling in Brittany (France): influence of vegetation type, season and weather conditions. Biological Conservation 97:189-198

Gallet S, Lemauviel S, Rozé F (2004) Responses of three heathland shrubs to single or repeated experimental trampling. Environmental Management 33:821-829

Gallet S, Bioret F, Helou A (2009) Quelles méthodes pour le suivi et l'évaluation des opérations de restauration écologique? Exemple de la Côte Sauvage de Quiberon. Ingénieries Special issue 62(3-4):73-81

Gallet S, Bioret F, Fichaut B, Sawtschuk J (2010) La phytosociologie, outil pertinent pour le suivi de la restauration écologique? Revue Forestière Française 62:409-416

Gallet S, Bioret F, Sawtschuk J (2011) La restauration des végétations des hauts de falaises du littoral atlantique, vers une évaluation globale. Sciences Eaux \& Territoires 5:12-19

Gallet S, Jaunatre R, Regnery B, Alignan J-F, Heckenroth A, Müller I et al. (2017) L'écologie de la restauration en France. Dynamique actuelle et rôle d'un réseau multi-acteurs, Rever. Naturae 7:1-11

Gerlach J, Samways M, Pryke J (2013) Terrestrial invertebrates as bioindicators: an overview of available taxonomic groups. Journal of Insect Conservation $17: 831-850$

Godínez-Alvarez H, Herrick JE, Mattocks M, Toledo D, Van Zee J (2009) Comparison of three vegetation monitoring methods: their relative utility for ecological assessment and monitoring. Ecological Indicators 9: $1001-1008$

González E, Rochefort L, Boudreau S, Hugron S, Poulin M (2013) Can indicator species predict restoration outcomes early in the monitoring process? A case study with peatlands. Ecological Indicators 32:232-238

Gonzalo-Turpin H, Couix N, Hazard L (2008) Rethinking partnerships with the aim of producing knowledge with practical relevance: a case study in the field of ecological restoration. Ecology and Society 13(2):53

Guerrero AM, Shoo L, Gwenllian I, Standish JR, Catterall CP, Libby R, Kelly de B, Zoe W, Virginia M, Wilson K (2017) Using structured decision-making to set restoration objectives when multiple values and preferences exist. Restoration Ecology 25:858-865

Gunderson L, Kinzig A, Quinlan A, Walker B, Cundhill G, Beler C, Crona B, Bodin Ö (2010) Assessing resilience in social-ecological systems: workbook for practitioners. Resilience Alliance, https://www.reefresilience.org/ pdf/ResilienceAssessment2.pdf

Hallett LM, Diver S, Eitzel MV, Olson JJ, Ramage BS, Sardinas H, Statman-Weil Z, Suding KN (2013) Do we practice what we preach? Goal setting for ecological restoration. Restoration Ecology 21:312-319

Halme P, Allen KA, Auniņš A, Bradshaw RHW, Brūmelis G, Čada V et al. (2013) Challenges of ecological restoration: lessons from forests in northern Europe. Biological Conservation 167:248-256

Hobbs RJ (2007) Setting effective and realistic restoration goals: key directions for research. Restoration Ecology 15:354-357

Hobbs RJ, Harris JA (2001) Restoration ecology: repairing the Earth's ecosystems in the new millennium. Restoration Ecology 9:239-246

Kerbiriou C (2006) Impact des changements d'usage sur la viabilité d'une population menacée dans un espace multi-protégé: Le Crave à bec rouge
(Pyrrhocorax pyrrhocorax) sur l'île d'Ouessant. PhD thesis. Museum National d'Histoire Naturelle, France, Paris

Kondolf GM, Anderson S, Lave R, Pagano L, Merenlender A, Bernhardt ES (2007) Two decades of river restoration in California: what can we learn? Restoration Ecology 15:516-523

Le Corre N (2009) Le dérangement de l'avifaune sur les sites naturels protégés de Bretagne: état des lieux, enjeux et réflexions autour d'un outil d'étude des interactions hommes/oiseaux. PhD thesis. Université de Bretagne Occidentale, Brest, France

Le Fur Y (2013) La patrimonialisation des grands sites: évolution des doctrines et transformation des espaces: exemple des promontoires littoraux emblématiques bretons. PhD thesis. Université de Bretagne Occidentale, Brest, France

Lebras G (2007) Inventaire des opérations de restauration et de réhabilitation des végétations des falaises du littoral Manche-Atlantique. Programme LITEAU II: Restauration et réhabilitation de la végétation des falaises littorales des côtes Manche-Atlantique. Université de Bretagne Occidentale, Institut de Géoarchitecture, Brest, France

Leis SA (2015) Comparison of vegetation sampling procedures in a disturbed mixed-grass prairie. Proceedings of the Oklahoma Academy of Science $83: 7-15$

Liddle MJ (1975) A selective review of the ecological effects of human trampling on natural ecosystems. Biological Conservation 7:17-36

Lowe P, Whitman G, Phillipson J (2009) Ecology and the social sciences. Journal of Applied Ecology 46:297-305

Malloch AJC (1972) Salt-spray deposition on the maritime cliffs of the Lizard Peninsula. Journal of Ecology 60:103-112

McDonald T, Gann GD, Jonson J, Dixon KW (2016) International standards for the practice of ecological restoration-including principles and key concepts. Society for Ecological Restoration. Soil-Tec, Inc, Washington D.C.

McIver J, Starr L (2001) Restoration of degraded lands in the interior Columbia River basin: passive vs. active approaches. Forest Ecology and Management 153:15-28

Metcalf EC, Mohr JJ, Yung L, Metcalf P, Craig D (2015) The role of trust in restoration success: public engagement and temporal and spatial scale in a complex social-ecological system. Restoration Ecology 23: $315-324$

Michel P, Mathieu R, Mark AF (2010) Spatial analysis of oblique photo-point images for quantifying spatio-temporal changes in plant communities. Applied Vegetation Science 13:173-182

Miller JR, Hobbs RJ (2007) Habitat restoration — do we know what we're doing? Restoration Ecology 15:382-390

Nordstrom KF, Mitteager WA (2001) Perceptions of the value of natural and restored beach and dune characteristics by high school students in New Jersey, USA. Ocean \& Coastal Management 44:545-559

Palmer MA, Falk DA, Zedler JB (2006) Ecological theory and restoration ecology. Pages 1-10. In: Falk DA, Palmer MA, Zedler JB (eds) Foundations of restoration ecology. Island Press, Washington D.C., Covelo, California, London, United Kingdom

Perring MP, Standish RJ, Price JN, Craig MD, Erickson TE, Ruthrof KX, Whiteley AS, Valentine LE, Hobbs RJ (2015) Advances in restoration ecology: rising to the challenges of the coming decades. Ecosphere $6: 1-25$

Petursdottir T, Aradottir AL, Benediktsson K (2013) An evaluation of the short-term progress of restoration combining ecological assessment and public perception. Restoration Ecology 21:75-85

Prach K, del Moral R (2015) Passive restoration is often quite effective: response to Zahawi et al. (2014). Restoration Ecology 23:344-346

Prach K, Hobbs RJ (2008) Spontaneous succession versus technical reclamation in the restoration of disturbed sites. Restoration Ecology 16:363-366

Prach K, Řehounková K, Lencová K, Jírová A, Konvalinková P, Mudrák O et al. (2014) Vegetation succession in restoration of disturbed sites in Central Europe: the direction of succession and species richness across 19 seres. Applied Vegetation Science 17:193-200 
Rissman AR, Gillon S (2017) Where are ecology and biodiversity in social-ecological systems research? A review of research methods and applied recommendations. Conservation Letters 10:89-93

Roux DJ, Rogers KH, Biggs H, Ashton PJ, Sergeant A (2006) Bridging the science-management divide: moving from unidirectional knowledge transfer to knowledge interfacing and sharing. Ecology and Society 11:4

Rozé F (1995) Restauration des landes littorales. Exemple: le Cap d'Erquy (Bretagne 22 F). Botanica Rhedonica: Nouvelle Série 4:39-45

Rumps JM, Katz SL, Barnas K, Morehead MD, Jenkinson R, Clayton SR, Goodwin P (2007) Stream restoration in the Pacific Northwest: analysis of interviews with project managers. Restoration Ecology 15:506-515

Saccone P, Virtanen R (2016) Extrapolating multi-decadal plant community changes based on medium-term experiments can be risky: evidence from high-latitude tundra. Oikos 125:76-85

Sawtschuk J (2010) Restauration écologique des pelouses et des landes des falaises littorales atlantiques: analyse des trajectoires successionnelles en environnement contraint. PhD thesis. Université de Bretagne Occidentale, Brest, France

Sawtschuk J, Bioret F, Gallet S (2010) Spontaneous succession as a restoration tool for maritime cliff-top vegetation in Brittany, France. Restoration Ecology 18:273-283

Sawtschuk J, Gallet S, Bioret F (2012) Evaluation of the most common engineering methods for maritime cliff-top vegetation restoration. Ecological Engineering 45:45-54
Sawtschuk J, Delatouche T, Bioret F, Robert C (2015) Évaluation écologique de la restauration et de la gestion des végétations littorales sur le territoire de Lorient Agglomération. Penn ar Bed 220:42-52

SER (2004) The SER international primer on ecological restoration. Society for Ecological Restoration International, Tucson, Arizona. www.ser.org

Weinstein MP (2007) Linking restoration ecology and ecological restoration in estuarine landscapes. Estuaries and Coasts 30:365-370

Wiens JA, Hobbs RJ (2015) Integrating conservation and restoration in a changing world. Bioscience 65:302-312

Wortley L, Hero J-M, Howes M (2013) Evaluating ecological restoration success: a review of the literature. Restoration Ecology 21:537-543

Wyborn C, Jellinek S, Cooke B (2012) Negotiating multiple motivations in the science and practice of ecological restoration. Ecological Management \& Restoration 13:249-253

Zahawi RA, Reid JL, Holl KD (2014) Hidden costs of passive restoration. Restoration Ecology 22:284-287

Zahawi RA, Reid JL, Holl KD (2015) Passive restoration can be an effective strategy: a reply to Prach and del Moral (2015). Restoration Ecology 23:347-348

\section{Supporting Information}

The following information may be found in the online version of this article:

Appendix S1. Guide for semistructured interviews. 